\title{
PEMAHAMAN MASYARAKAT TERHADAP KEBIJAKAN PUBLIK DI DESA PH KECAMATAN BBL, BEKASI, JAWA BARAT
}

\author{
Dennis Akbar Satrio ${ }^{1}$ \\ ${ }^{1}$ Sekolah Tinggi Ilmu Administrasi -YPIAMI, Jakarta \\ Email: dennis.asatrio@gmail.com
}

\begin{abstract}
Village communities have socio-cultural values and close kinship relationships maintains the values. In the national development, village communities also demand public policies that stand on the people's side for prosperity achievement. However, the village community does not fully understand various public service programs of welfare improvement in their village. In this matter, all public policies coming from the regional and central government regarding public welfare must be known in all levels of society. It does not only relate to community groups that are geographically close to the government center. The research purpose is to obtain the holistic picture of the understanding of rural communities towards public policies with the villagers' welfare orientation. This research used a qualitative method with the deliberate decision of the informants to obtain the required data and information. The research results show that the people of $\mathrm{PH}$ Village definitely does not know and understand various public policies for welfare improvement. Another research results indicate that the socialization of the public policies faces obstacles for internal factors in the government work units and otherwise, the public do not care about the welfare improvement programs.
\end{abstract}

Keywords: village, village community, public policy, community welfare, local government

\begin{abstract}
ABSTRAK
Masyarakat desa memiliki nilai - nilai sosial budaya yang dipertahankan dalam hubungan kekerabatan yang erat. Sejalan dengan perkembangan pembangunan, masyarakat desa juga menuntut kebijakan publik yang berpihak kepada rakyat demi tercapainya kesejahteraan. Kendati demikian masyarakat desa ternyata tidak sepenuhnya mengetahui berbagai program pelayanan public untuk meningkatkan kesejahteraan untuk masyarakat. Padahal semua kebijakan publik yang berasal dari pemerintah daerah maupun pemerintah pusat menyangkut kesejahteraan harus diketahui oleh seluruh lapisan masyarakat. Bukan hanya kelompok masyarakat yang secara geografis dekat dengan pusat pemeritahan saja. Tujuan penelitian ini adalah untuk memperoleh gambaran holistik terhadap pemahaman masyarakat desa terhadap kebijakan publik yang berorientasi untuk kesejahteraan warga desa. Penelitian ini menggunakan metode kualitatif dengan penetapan informan secara sengaja untuk memperoleh data dan informasi yang diperlukan. Hasil penelitian menunjukkan, bahwa masyarakat Desa PH belum mengetahui dan memahami berbagai kebijakan publik yang memberikan pelayanan publik untuk meningkatkan kesejahteraan. Temuan lain adalah sosialisasi kebijakan publik mengalami hambatan karena faktor internal di unit - unit kerja pemerintahan dan masyarakat yang kurang peduli terhadap program peningkatan kesejahteraan.
\end{abstract}

Kata Kunci: desa, masyarakat desa, kebijakan publik, kesejahteraan masyarakat, pemerintah di daerah

\section{PENDAHULUAN}

\section{Latar Belakang}

Pedesaan di Indonesia memiliki karakter yang masih mengandalkan hubungan kekerbatan dan menjaga nilai - nilai sosial budaya pedesaan dalam kehidupan sehari - hari. Walaupun teknologi dan perkembangan wilayah sudah merambah ke pedesaan, tetapi perilaku dan karakter masyarakat desa di lingkungannya sendiri masih berusaha untuk mengikuti dan mempertahankan adat istiadat yang diyakini dalam kehidupan sehari - hari.

Secara singkat masyarakat merupakan sekumpulan manusia saling bergaul, dan berinteraksi dalam satuan sosial yang memiliki keteraturan secara berulang- ulang (Koentjaraningrat, 2012). Dalam pandangan Ralph Linton masyarakat merupakan kelompok manusia yang hidup bekerja sama sehingga dapat mengorganisasi dirinya dan berfikir tentang dirinya sebagai satu kesatuan 
social dengan batas-batas tertentu (Soekanto, 2017). Sedangkan pendapat lain dari Herskovits menegaskan bahwa masyarakat adalah kelompok individu yang dikoordinasikan dan mengikuti satu cara hidup tertentu sesuai dengan karakteristik lingkungannya (Wiranata, 2011). Sedangkan desa adalah tempat tinggal dari suatu masyarakat yang relative kecil, dan ditandai oleh ikatan kebersamaan dalam satu wilayah tertentu (Syarif \& Zaenuddin, 2017). Berdasarkan hal tersebut masyarakat desa adalah sekelompok masyarakat yang saling berinteraksi dalam suatu wilayah dengan ikatan kebersamaan yang kuat. Menurut Bintarto, desa merupakan suatu hasil perpaduan antara kegiatan sekelompok manusia dengan lingkungannya. Hasil dari perpaduan itu ialah suatu wujud atau kenampakan di muka bumi yang ditimbulkan oleh unsur-unsur fisiografi, social, ekonomi, politik dan cultural yang saling berinteraksi antar unsur tersebut dan juga dalam hubungannya dengan daerah-daerah lain (Wijayanti \& Pratomo, 2019).

Menurut Undang-Undang Nomor 6 Tahun 2014 tentang Desa, desa merupakan kesatuan masyarakat hukum yang memiliki batas wilayah yang berwenang untuk mengatur dan mengurus urusan pemerintahan, kepentingan masyarakat setempat berdasarkan prakarsa masyarakat, hak asal usul, dan/atau hak tradisional yang diakui dan dihormati dalam sistem pemerintahan Negara Kesatuan Republik Indonesia. Berpijak pada pengertian masyarakat dan desa di atas, maka masyarakat desa adalah masyarakat yang masih mempercayai dan menjalankan nilai-nilai sosial budaya secara turin temurun dan menempati wilayah pedesaan yang relatif jauh dari perkotaan. Masyarakat pedesaan dinilai sulit berkembang karena kebiasaan yang dianggap tidak produktif karena lebih banyak menekankan pada kekerabatan. Walaupun memiliki kekuatan sebagai kelompok masyarakat yang konsisten terhadap pelembagaan nilai tradisional sebagai ketahanan dalam kehidupan masyarakat yang harmoni (Susanto, 2009).

Masyarakat desa seringkali dikatakan sebagai masyarakat tradisional yang masih mempertahankan nilai sosial budaya secara turun temurun sebagai landasan dalam kehidupan. Menurut Soemardjan (1993) dalam Roso (2019), masyarakat tradisional bersifat homogen, memiliki rasa kekeluargaan, kesetiakawanan, kesadaran kolektif dan pranata adat yang efektif untuk menghidupkan disiplin sosial. Kondisi masyarakat Desa PH Kecamatan BBL, Bekasi Jawa Barat juga memiliki karakteristik yang sama dengan ciri - ciri masyarakat desa dalam telaah akademis.

Mengingat karakteristik masyarakat desa diatas, maka pemerintahan di daerah dalam menerapkan suatu kebijakan public harus memperhatikan pula kondisi masyarakat desa. Bagaimanapun juga, keberadaan pemerintah di daerah adapah untuk mengatur dan mengurus masyarakat tanpa diferensiasai sosial budaya, ekonomi dan politik. Pemerintahan yang berjalan dengan baik jika mampu mewujudkan kesejahteraan melalui berbagai kebijakan publik yang berpihak kepada seluruh masyarakat tanpa perbedaan. Kebijakan publik yang dikeluarkan oleh pemerintah daaerah, maupun pemerintah daerah hanya sebagai pelaksana kegiatan program pemerintah dalam skala nasional bertujuan untuk menciptakan kesejahteraan masyarakat termasuk masyarakat desa (Sunarno, 2012).

Pemerintah dapat berbuat secara otoritatif untuk seluruh masyarakat, dan semuanya yang dipilih oleh pemerintah untuk dikerjakan atau untuk tidak dikerjakan adalah hasil-hasil dari nilai-nilai tersebut (Thoha, 2017). Karena itu, penyelenggaraan pemerintahan di daerah erat hubungannya dengan upaya mewujudkan kesejahteraan masyarakat. Artinya, kebijakan publik harus benar benar dibuat untuk kepentingan dan keinginan masyarakat. kebijakan publik bukan dibuat demi kepentingan kelompok tertentu yang berpengaruh di masyarakat maupun kepentingan pejabat publik dalam dalam menjalankan pemerintahan. 
Hakikatnya kebijakan publik berlaku bagi seluruh masyarakat, karena itu masyarakat pedesaan juga harus diperhatikan dan mereka wajib mengetahui berbagai kebijakan publik untuk kepentingan masyarakat. Kebijakan publik merupakan segala sesuatu keputusan yang bersangkut paut dengan kepentingan masyarakat. Thomas R. Dye menyatakan bahwa "kebijakan publik adalah segala sesuatu yang dipilih dan dikerjakan pemerintah (Kencana, 2016).

Sebagai pelaksana kebijakan publik, pemerintahan di daerah beserta organ - organ kekuasaannya harus memperhatikan bahwa kebijakan publik dampaknya dirasakan oleh masyarakat termasuk di pedesaan. Terlebih lagi di era otonomi daerah, kebijakan publik di tingkat kabupaten harus mampu mampu meningkatkan kesejahteraan warga desa (Lesmana, 2017). Kebijakan publik menunjukkan tindakan yang dilaksanakan oleh aparatur negara dalam memecahkan persoalan di masyarakat (Anderson, 2003). Sementara itu menurut T.B. Smith, kebijakan publik yang dibuat harus dapat diimplementasikan dan hasilnya sedapat mungkin sesuai dengan apa yang diharapkan oleh pembuat kebijakan untuk menunjukkan bahwa suatu kebijakan memiliki tujuan jelas dan diwujudkan dalam program kegiatan. (Akib, 2010). Perwujudan kegiatan harus menyeluruh termasuk masyarakat pedesaan yang tentunya secara geografis memiliki jarak yang cukup jauh dan tidak mudah untuk dijangkau.

Kebijakan publik yang berpihak kepada masyarakat desa mendorong penerimaan positif masyarakat sebagai bentuk dukungan terhadap program pemerintah (Winarno, 2012). Walaupun bisa saja menimbulkan kritik terhadap pelaksanaan kebijakan public ketika terdapat berbagai celah yang tidak sejalan dengan harapan masyarakat. Namun dalam kondisi ini, aparatur pemerintah harus memposisikan kriktik tersebut sebagai masukan berharga untuk menjalankan kegiatan lebih baik lagi. Sebab kebijakan publik merupakan regulasi, tindakan, dan prioritas pendanaan mengenai program kegiatan tertentu yang dikerjakan oleh pemerintah maupun entitas perwakilannya (Evans, 2008).

Berbagai faktor yang menghambat pelaksanaan kebijakan publik pada umumnya terjadi karena faktor internal pada unit kerja yang berwenang dalam penyelenggaraan kegiatan. Hal ini menyebabkan masyarakat desa terlambat dalam mengetahui kebijakan publik yang bertujuan memberikan pelayanan dan kesejahteraan yang lebih baik. Antar unit - unit yang bertanggungjawab terhadap kebijakan publik tidak sama dalam menafisirkan aturan untuk pelayanan kepada publik.

Selain itu berbagai kebijakan publik tidak disosialisasikan dan didifusikan dengan cepat kepada masyarakat desa. Karena untuk menyebarkan informasi ke desa - desa tidak ada koordinasi secara berkesinambungan dari unit kerja yang bertanggungjawab terhadap kebijakan publik. Di sisi lain, koordinasi di unit kerja di tingkat kabupaten dengan aparatur di pemerintahan desa tidak rutin dan lamban, sehingga pelaksanaan kebijakan publik tidak berjalan lancar.

Berpijak kepada uraian di atas, masalah penelitian ini adalah: (1) Apakah masyarakat desa sudah mengetahui berbagai kebijakan publik terkait kesejahteraan yang dikeluarkan oleh pemerintah setempat maupun pemerintah pusat? (2) Apakah upaya penyebaran informasi dan sosialisasi kebijakan publik dari pemerintah daerah mengalami hambatan karena faktor internal di unit unit kerja pemerintahan di daerah? Tujuan penelitian ini adalah untuk memperoleh gambaran secara menyeluruh terhadap pemahaman masyarakat desa tentang kebijakan publik yang berupaya untuk meningkatkan kesejahteraan masyarakat desa. 


\section{METODE PENELITIAN}

\section{Partisipan dan Prosedur Penelitian}

Penelitian tentang kebijakan Publik di Desa PH ini menggunakan metode kualitatif untuk memahami makna interaksi individu, kelompok maupun institusi dalam kaitannya dengan hubungan antar manusia, maupun manusia dengan lingkungannya.

Menurut Bogdan dan Taylor (dalam Moleong, 2018), penelitian kualitatif adalah prosedur penelitian yang menghasilkan data deskriptif berupa kata-kata tertulis atau lisan dari orang yang sedang diamati beserta perilakunya. Sumber data dalam penelitian kualitatif berasal dari catatan, rekaman audio, video dan data online dari berbagai website, media online maupun sumber data lain berbasais teknologi digital (Bungin, 2016).

Subjek dalam penelitian ini adalah masyarakat desa PH, dan informan penelitian yang ditetapkan secara purposive. Penelitian ini dilaksanakan pada bulan September 2017 di Desa PH Kecamatan BBL, Kabupaten Bekasi, Provinsi Jawa Barat. Untuk memperoleh data dan informasi yang sesuai dengan topik penelitian ditetapkan informan penelitian yang menggunakan teknik purposive sampling dengan pola snowball. Teknik purposive sampling dengan snowball merupakan teknik mengambil informan atau narasumber dengan tujuan tertentu sesuai dengan tema penelitian karena orang tersebut dianggap memiliki informasi yang diperlukan bagi penelitian (Sugiyono, 2016). Terdapat 9 informan berdasarkan teknik snowball, mencakup syarat: warga $\mathrm{PH}$, minimlal berumur minimal 25 tahun, pendidikan sekurang - kurangnya lulus Sekolah Dasar, dan tinggal di desa setempat secara berturut - turut paling sedikit lima tahun. Usia dan jangka waktu tersebut dianggap memadai untuk memberikan informasi kondisi dan dinamika perkembangan pedesaan dari aspek kesejahteraan. Penyebutan informan dalam penelitian ini adalah A, B, C, D, E, F, G, H dan I.

Di samping itu teknik pengumpulan data dilakukan dengan metode observasi, dokumentasi, wawancara, dan sumber non-manusia (non-human source of information) mencakup dokumen, dan rekaman (record) yang tersedia. (Faisal, 2015). Pengumpulan data difokuskan kepada kebijakan publik yang baik seharusnya dapat memberikan kesejahteraan masyarakat desa (Patarai, 2020). Analisis data dilakukan dengan melakukan pemilahan berbagai informasi untuk dikelompokkan dalam deskripsi tertentu. Data dan informasi yang tidak sesuai dengan topik penelitian akan disingkirkan. Tujuan agar hasil analisis data tidak melebar dan kurang sejalan dengan topik penelitian yang dapat menggambarkan peristiwa secara menyeluruh.

\section{HASIL DAN PEMBAHASAN}

\section{Gambaran singkat Desa PH dan karakter informan}

Secara administratif, Desa PH Jaya termasuk salah satu desa dari sembilan desa yang berada di wilayah Kecamatan BBL, Kabupaten Bekasi. Luas wilayah Kecamatan BBL sekitar 5.712,62 hektar, 80 persen dari luas wilayah merupakan daerah lahan terbuka atau daerah pertanian. Desa PH berbatasan langsung dengan Kecamatan Muara Gembong dan menjadi salah satu lokasi tambang galian milik perusahaan pemerintah itu.

Jumlah penduduk berdasarkan monografi desa pada tahun 2017 sebanyak 4.724 orang yang terdiri atas 2.423 orang penduduk laki-laki dan 2.301 orang penduduk perempuan, dengan jumlah kepala keluarga 1.470 dan jumlah rumah 1.382. Mata pencaharian penduduk desa PH sebagian besar adalah petani 364 orang pemilik lahan sempit, buruh tani 542 orang, buruh swasta 250 orang, Pegawai Negeri Sipil 25 orang, pedagang kecil dalam lingkup non formal 200 orang, nelayan 122 orang, sopir 4 orang, tukang bangunan 30 orang. 
Berdasarkan data dari Kabupaten Bekasi ada berbagai kegiatan yang berhubungan dengan peningkatan kesejahteraan masyarakat yang berasal dari Kabupaten maupun program pemerintah pusat yang mencakup juga pelaksanaan kegiatannya di Desa PH. Kebijakan publik yang diimplementasikan berhubungan dengan faktor sosial-budaya dan perekonomian yang difokuskan untuk memperoleh hak dan pelayanan sama dalam memperoleh kesejahteraan material maupun spiritual.

Karakteristik informan penelitian warga Desa PH yang ditetapkan secara sengaja dengan persyaratan tertentu, selengkapnya tertera pada tabel 1 berikut:

\section{Tabel 1. Karakter informan Desa PH}

Sumber: Hasil Pengolahan Data

\begin{tabular}{lll}
\hline Identitas & Umur/ Jenis Kelamin & Profesi/ Mata Pencaharian \\
\hline $\mathrm{A}$ & 45 tahun/ Laki - laki & Petani dan pekerja serabutan \\
\hline $\mathrm{B}$ & 38 tahun/ Laki - laki & Petani dan pedagang informal \\
\hline $\mathrm{C}$ & 52 tahun/ Laki - laki & Nelayan tradisional \\
\hline $\mathrm{D}$ & 30 tahun / Perempuan & Buruh tani dan berjualan makanan \\
\hline $\mathrm{E}$ & 40 tahun/ Laki - laki & Buruh pabrik disekitar desa \\
\hline $\mathrm{F}$ & 60 tahun/ Laki - laki & Petani pemilik lahan sempit dan buruh \\
\hline $\mathrm{G}$ & 22 tahun/ Laki -laki & Pedagang asongan di kawasan pabrik \\
\hline $\mathrm{H}$ & 45 tahun/ Laki - laki & Pegawai kontrak di institusi pemerintah \\
\hline $\mathrm{I}$ & 32 tahun/ Perempuan & Pedagang informal dan buruh tani \\
\hline
\end{tabular}

Berdasarkan tabel di atas, maka kisaran umur dari informan penelitian ini adalah paling rendah 22 tahun seorang laki-laki pedagang asongan. Sedangkan umur tertinggi adalah 60 tahun, warga senior yang memiliki lahan pertanian sempit dan merangkap juga sebagai buruh tani di lahan pertanian warga desa yang lain. Para informan di atas memiliki aktivitas dan informasi yang memadai untuk mendukung topik penelitian. Semua informan selalu mengidentifikadsikan diri sebagai warga desa yang akarab dengan pertanian dan nelayan.

\section{Pengetahuan masyarakat Desa terhadap kebijakan publik}

Masyarakat Desa PH pada umumnya menggantungkan penghasilan dari sektor pertanian dan perikanan. Namun dalam skala kecil yang memiliki taraf hidup yang belum sejahtera. Mata pencaharian sebagai petani pada umumnya buruh tani, dan petani pemilik sawah yang memiliki lahan sempit. Profesi sebagai nelayan sebagaian besa didominasi oleh nelayan tradisional dengan peralatan sederhana dengan jangkau mencari ikan tidak luas.

Dalam kondisi yang kurang sejahtera, masyarakat desa tidak memiliki kepedulian berbagai program pedesaan yang dapat meningkatan kesejahteraan mereka. Pengetahuan dan pemahaman terhadap berbagai kebijakan publik dalam bentuk program pemerintah daerah maupun pemerintah pusat, yang diselenggarakan di Desa PH yang dikelompokkan sebagai kecenderungan utama. Kecenderungan didasarkan pada pendapat informan yang memiliki kesamaan sekurang-kurangnya dikemukakan oleh 5 (lima) orang dari 9 orang informan yang dimintai pendapat. Secara rinci pendapat informan dapat dilihat pada table 2 dibawah ini. 
Tabel 2. Jenis kebijakan publik dan kecenderungan pengetahuan masyarakat berdasarkan pendapat informan

Sumber: Hasil Pengolahan Data

\begin{tabular}{|c|c|c|c|}
\hline No & $\begin{array}{l}\text { Jenis Kebijakan Publik dalam } \\
\text { Program Kegiatan }\end{array}$ & $\begin{array}{l}\text { Kelompok } \\
\text { Informan }\end{array}$ & $\begin{array}{l}\text { Deskripsi Pengetahuan terhadap } \\
\text { Kebijakan Publik }\end{array}$ \\
\hline 1 & $\begin{array}{l}\text { Harmonisasi \& Toleransi } \\
\text { Antar Ummat Beragama }\end{array}$ & $\begin{array}{l}\text { A, B, C, D, E, H } \\
\text { dan G }\end{array}$ & $\begin{array}{l}\text { Mengetahui dan pernah mengikuti } \\
\text { kegiatan dalam berbagai kegiatan } \\
\text { desa }\end{array}$ \\
\hline 2 & $\begin{array}{l}\text { Mendorong pelestarian seni } \\
\text { budaya lokal }\end{array}$ & $\begin{array}{l}\text { A, B, D, E, F dan } \\
\text { I }\end{array}$ & $\begin{array}{l}\text { Tidak Mengetahui yang dimaksud } \\
\text { dengan pelestarian budaya lokal }\end{array}$ \\
\hline 3 & $\begin{array}{l}\text { Kesejahteraan sosial bagi para } \\
\text { lanjut usia }\end{array}$ & $\begin{array}{l}\text { B, C, D, E, F, G, } \\
\text { dan I }\end{array}$ & $\begin{array}{l}\text { Tidak pernah tahu ada program } \\
\text { ini, tetapi adakalanya orang lanjut } \\
\text { usia dibantu, tapi tidak tahu } \\
\text { bantuan dari pihak mana }\end{array}$ \\
\hline 4 & Kesejahteraan bagi disabilitas & $\begin{array}{l}\text { A, B, C, D, E, F, } \\
\text { G dan I }\end{array}$ & Tidak tahu kalau ada program ini \\
\hline 5 & Kesejahteraan guru honorer & $\begin{array}{l}\text { A, B, C, D, E, F, } \\
\text { G, H, dan I }\end{array}$ & $\begin{array}{lcr}\text { Mengetahui } & \text { ada } & \text { program } \\
\text { kesejahteraan } & \text { guru, } & \text { karena } \\
\text { banyak warga desa cerita } & \\
\end{array}$ \\
\hline 6 & Bantuan biaya pendidikan & $\begin{array}{l}\text { A, B, C, D, E, F, } \\
\text { G dan H }\end{array}$ & $\begin{array}{l}\text { Bantuan pendidikan untuk anak } \\
\text { sekolah bebas biaya masuk dan } \\
\text { sekolah negeri }\end{array}$ \\
\hline 7 & $\begin{array}{l}\text { Tanggungjawab Sosial } \\
\text { Perusahaan }\end{array}$ & A, B, C, D, dan I & $\begin{array}{l}\text { Tidak mengetahui Adanya } \\
\text { tanggungjawab perusahaan } \\
\text { terhadap masyarakat desa }\end{array}$ \\
\hline 8 & $\begin{array}{l}\text { Menjadikan lahan pertanian } \\
\text { produktif }\end{array}$ & $\begin{array}{l}\text { A, B, C, D, E, H } \\
\text { dan I }\end{array}$ & $\begin{array}{l}\text { Mengetahui dari seringnya } \\
\text { undangan warga desa untuk } \\
\text { mengikuti penyuluhan pertanian }\end{array}$ \\
\hline 9 & $\begin{array}{l}\text { Pengembangan wisata Pesisir } \\
\text { Laut Utara Bekasi }\end{array}$ & $\begin{array}{l}\text { A, C, D, E, F dan } \\
\text { G }\end{array}$ & $\begin{array}{l}\text { Tidak Mengetahui Adanya upaya } \\
\text { Pengembangan wisata di pesisir } \\
\text { Bekasi }\end{array}$ \\
\hline
\end{tabular}

Berdasarkan tabel di atas dapat diketahui bahwa masyarakat desa Panati Hurip pada umumnya tidak mengetahui berbagai program pemerintah yang berhubungan dengan upaya peningkatan kesejahteraan. Terdapat kecenderungan masyarakat untuk mengetahui program Pemerintah, jika program kebijakan publik itu menjadi pembicaraan sehari-hari warga desa. Mereka juga memperoleh informasi dari berbagai sumber, dalam tatap muka langsung maupun pemberitaan radio, televisi maupun media sosial. Kondisi ini sejalan dengan konsep opini publik yang menyatakan bahwa fenomena pengetahuan khalayak dibentuk oleh proses komunikasi yang dinamis dalam suatu arus informasi. Karena itu program pemerintah yang diketahui warga desa adalah yang menjadi pembicaraan masyarakat di pedesaan (Noviyanti \& Soleh, 2017).

Pengetahuan terhadap masalah yang terkait dengan kesejahteraan guru, bantuan pendidikan untuk siswa sekolah negeri, hampir diketahui oleh semua masyarakat mengingat program itu seperti klise dan selalu muincul dalam berbagai pidato elite di pedesaan. Apalagi bahwa janji tentang pendidikan gratis dan perhatian terhadap kesejahteraan guru selalu muncul dalam pemilihan kepala daerah. Sudah barang tentu terkmasuk di kabupaten Bekasi Provinsi Jawa Barat.

Program kesejahteraan yang tidak diketahui secara jelas oleh warga desa pada umumnya yang berhubungan dengan kegiatan spesifik yang menyangkut kelompok masyarakat tertentu seperti halnya kesejahteraan bagi warga disabilitas dan lansia. Pengetahuan merekapun sebatas pada 
pengalaman menyaksikan adanya sumbangan untuk orang berusia lanjut, tetapi tidak mengetahui dengan jelas, apakah itu diselenggarakan pemerintah atau kelompok masyarakat lain yang memiliki status sosial ekonomi lebih baik.

Namun yang cukup mengherankan adalah ketidaktahuan terhadap upaya pengembangan wisata pesisir, mengingat $\mathrm{PH}$ adalah kawasan pesisir yang memiliki potensi wisata yang baik. Kondisi ini sejalan dengan penelitian tentang Bantuan Langsung Tunai (BLT)yang dilakukan Sunaryo (2014), bahwa mengorganisasikan kesejahteraan masyarakat dalam kebijakan publik hanya dikaitkan dengan kinerja organisasi pemerintah yang normatif. Bukan pelaksanaan kebijakan publik yang menjadi hak masyarakat sebagai pihak yang wajib memperoleh pelayanan dari pemerintah.

Masyarakat Desa PH sebagaimana masyarakat lainnnya di seluruh penjuru tanah air harus memperoleh kesejahteraan yang sama secara moral maupun material dalam implementasi kebijakan publik. Menurut David Easton, kebijakan publik merupakan rangkaian dari upaya dan tindakan yang dilakukan pemerintah beserta unit-unit organisasinya untuk kepentingan publik atau masyarakat (Agustino, 2016). Pencapaian kesejahteraan rakyat juga telah diamanatkan dalam berbagai peraturan yang menyatakan bahwa setiap orang berhak hidup sejahtera lahir dan batin. Menjamin bertempat tinggal, mendapatkan lingkungan hidup yang baik dan sehat, memperoleh pelayanan kesehatan, kesempatan yang sama dalam proses peradilan, dan berbagai hak lain yang berhubungan dengan posisi rakyat Indonesia. Namun di tingkat pedesaan pemenuhan itu terabaikan, karena itu diperlukan model perencanaan desa yang efektif untuk mencapai kesejahteraan desa (Koeswara, 2019). Hakikatnya pencapaian kesejahteraan masyarakat desa melalui kebijakan publik harus dilakukan dengan perencanaan yang baik.

\section{Sosialisasi kebijakan publik menyangkut kesejahteraan}

Kebijakan publik mempunyai tujuan tertentu dan dilaksanakan oleh pemerintah maupun aparatur pejabat pemerintah. Kebijakan publik yang berpihak kepada masyarakat mengandung unsur kebaikan yang mampu memberikan kesejahteraan kepada masyarakat. Pemerintah tidak memposisikan sebagai pihak yang dominan, tetapi sebagai pelayan masyarakat (Muliawaty \& Hendryawan, 2020). Namun masyarakat desa yang jauh dari pusat pemerintahan di tingkat Kabupaten belum sepenuhnya merasakan Manfaat nyata terhadap berbagai hal yang sesungguhnya menjadi hak mereka untuk ikut merasakan program pemerintah tersebut.

Memang ada kebijakan publik sangat dikenal oleh masyarakat Desa $\mathrm{PH}$, tetapi ada pula program pemerintah yang tidak diketahui sepenuhnya. Masyarakat desa merasa hanya mendengar atau memperoleh kabar yang tidak utuh. Disisi lain mereka juga merasakan bahwa program tersebut belum terwujud di Desa PH. Tetapi seungguhnya ketidaktahuan masyarakat bukan semata karena sosialisasi program yang kurang berjalan dengan baik, adakalanya masyarakat sendiri cenderung tidak mau tahu, apatis dan lamban dalam menerima informasi, merespon himbauan atau ajakan untuk berparitisipasi dalam program kesejahteraan desa.

Kondisi diatas berbeda dengan hasil penelitian kesejahteraan masyarakat di Desa Sibubur, Dolok, Kabupaten Padang Lawas Utara, Sumatera Utara. Program kesejahteraan masyarakat tidak terlepas dari implementasi kebijakan anggaran dana desa dan menyangkut pula jaringan kekuatan politik, ekonomi, dan sosial yang langsung maupun tidak langsung berhubungan dengan aparatur pedesaan. (Elvina \& Musdhalifah, 2019). Esensinya kebijakan publik untuk menyejahterakan masyarakat desa dapat berjalan jika ada kekuatan - kekuatan politik, ekonomi dan keberadaan tokoh masyarakat yang mendukung. 
Terdapat berbagai kendala dalam penerapan kebijakan yang bertujuan untuk memberikan kesejahteraan kepada masyarakat, khususnya di Desa PH. Aspek yang sangat menonjol adalah informasi yang terlambat diterima oleh warga desa. Hambatan lain, kompleksitas program yang menyangkut unit - unit kerja di lingkungan pemerintah, dan perilaku masayarakat yang cenderung lamban dalam menyikapi program pemerintah. Bahkan dalam implementasi kegiatan bisa muncul kelompok kepentingan untuk menarik keuntungan pribadi. Namun faktor ini tidak menonjol di desa karena semangat kolektivitas warga desa yang sangat baik menjaga kebersamaan.

Gambaran singkat dari hambatan pelaksanaan kebijakan publik yang berorientasi untuk kesejahteraan masyarakat desa tersebut dapat dilihat pada table 3 dibawah ini

Tabel 3. Hambatan pelaksanaan kebijakan publik di Desa PH Sumber: Hasil Pengolahan Data

\begin{tabular}{llll}
\hline No & $\begin{array}{l}\text { Jenis } \\
\text { Hambatan }\end{array}$ & Deskripsi Hambatan & Kecenderungan Pernyataan Informan \\
\hline 1 & Informasi & $\begin{array}{l}\text { Informasi yang diterima } \\
\text { masyarakat desa } \\
\text { terlambat. }\end{array}$ & $\begin{array}{l}\text { Memperoleh informasi bukan dari sumber } \\
\text { resmi tetapi dari media sosial dan sumber- } \\
\text { sumber tidak resmi di luar aparatur } \\
\text { pemerintah }\end{array}$ \\
\hline 2 & Kompleksitas & $\begin{array}{l}\text { Program menyangkut } \\
\text { berkaiatan dengan lintas } \\
\text { unit Lembaga } \\
\text { pemerintah }\end{array}$ & $\begin{array}{l}\text { Mendengar kabar bahwa pelaksanaan } \\
\text { program itu masih dalam proses Koordinasi } \\
\text { antara pihak pejabata yang berwenang atau } \\
\text { pemerintah }\end{array}$ \\
\hline 3 & Respon & $\begin{array}{l}\text { Masyarakat seringkali } \\
\text { lamban dalam merespon } \\
\text { kebijakan public, } \\
\text { padahal ini untuk } \\
\text { kepentingan warga desa }\end{array}$ & $\begin{array}{l}\text { Perilaku kelambanan muncul karena skeptis } \\
\text { terhadap program yang dijalankan karena } \\
\text { janji kesejahteraan seringkali didengar tetapi } \\
\text { perwujudannya yang tidak sesuai harapan. }\end{array}$ \\
& & $\begin{array}{l}\text { Kepentingan kelompok } \\
\text { di desa berupaya } \\
\text { menarik keuntungan } \\
\text { materi maupun } \\
\text { dukungan }\end{array}$ & $\begin{array}{l}\text { Ada kelompok yang mencari keuntungan } \\
\text { dalam pelaksanaan program pemerintah } \\
\text { dengan tindakan yang merugikan masyarakat }\end{array}$ \\
\hline 4 & Kepentingan & \\
Kelompok & &
\end{tabular}

Berdasarkan tabel 3, dapat diketahui bahwa hambatan dalam pelaksnaan kebijakan publik amat beragam. Keterlambatan informasi merupakan hambatan utama dalam program pemerintah. Warga desa sudah mengetahui lebih awal melalui berbagai sumber yang dipercaya melalui interaksi sesama warga desa. Masyarakat Desa PH juga dapat dengan mudah meanfaatkan perangkat teknologi komunikasi untuk berbagi informasi khususnya di kalangan anak muda.

Sedangkan yang tidak memiliki perangkat teknologi komunikasi misalnya yang paling sederhana telepon seluler, tetapi mereka bisa dengan mudah mendapat informasi karena interaksi pedesaan sangat baik dan berbagi informasi adalah hal yang sering dilakukan. Kondisi ini sejalan dengan teori teknologi komunikasi yang bersumber dari E. Rogers, bahwa teknologi dapat memberikan kesempatan kepada semua orang untuk memperoleh informasi sesuai kebutuhan (Badri, 2017). Hambatan lain adalah faktor birokrasi dalam pelaksanaan kegiatan yang melibatkan berbagai unit kerja di tubuh pemerintahan di daerah. Ini mengakibatkan implementasi menjadi terlambat, masyarakat menunggu lama realisasi program kesejahteraan. Padahal penelitian Fahturrahman (2016) tentang Birokrasi dan Implementasi Kebijakan Publik di Banten menunjukkan birokrasi 
mendukung kelancaran implementasi kebijakan publik, sehingga ada kesesuaian antara harapan masyarakat terhadap pelayanan yang lebih baik dan upaya yang dilakukan unit - unit kerja di pemerintahan.

Namun memang berbeda dengan kondisi masyarakat desa PH, birokrasi menjadi hambatan kelancaran implementasi kebijakan publik. Ditambah lagi dengan masyarakat desa yang lamban dalam merespon program kesejahteraan, maka tercapainya kesejahteraan juga terganggu. Penelitian lain di Desa Pakutandang Kecamatan Ciparay Kabupaten Bandung, menunjukkan hambatan pelaksanaan kebijakan publik di tingkat desa adalah pergantian perangkat desa menyebabkan keterlambatan pelaksanaan kegiatan di desa (Mulyadi 2019).

Sedangkan masyarakat desa PH menilai upaya mensejahterakan seringkali dikemukakan pada berbagai pertemuan di pedesaan oleh elite desa, tetapi perwujudannya belum sepenuhnya sesuai harapan. Walaupun tidak dapat diabaikan ada berbagai kebijakan untuk menyejahterakan rakyat dapat dinikmati oleh warga desa. Esensinya kelambanan dan sikap skeptis warga desa tidak terlepas dari pengalaman yang mereka rasakan dalam urusan kesejahteraan

Faktor lain yang merupakan hambatan, walaupun tidak menjadi faktor yang sangat menonjol adalah pelaksanaan kebijakan publik tentang upaya peningkatan kesejahteraan masyarakat dimanfaatkan oleh orang - orang yang memiliki kepentingan dalam memperoleh keuntungan pribadi. Selain itu tidak jarang bahwa berbagai macama bantuan untuk kesejahteraan warga desa dikaitkan pula dengan upaya menarik dukungan dalam persaingan diantara mereka yang berkepentingan.

\section{KESIMPULAN DAN SARAN}

Pemahaman Masyarakat Desa terhadap Kebijakan Publik masih terbatas hanya berkisar pada program pemerintah yang popular dan sering menjadi pembicaraan masyarakat. Sedangkan kebijakan public lainnya yang berupaya memberikan kesejahteraan kepada masyarakat dalam komunitas terbatas atau di luar jangkauan pemikiran masyarakat, seperti aktivtas budaya daerah, warga lanjut usia, difabel, tanggungjawab perusahaan terhadap masyarakat desa, wisata bahari yang sesungguhnya penting juga cenderung tidak diketahui dan dirasakan oleh warga desa setempat.

Sosialisasi kebijakan publik yang bermuatan upaya pemerintah dalam menyejahterakan rakyat atau melakukan pelayanan publik yang lebih baik tidak berjalan secara rutin. Terdapat hambatan dalam kelambatan informasi, Pelaksanaan program yang birokratis, respon masyarakat yang kurang memadai dan munculnya kepentimgan kelompok yang berupaya memanfaatkan program pemerintah untuk mencari Keuntungan.

Aparatur pemerintahan desa seyogianya menjalin hubungan yang integrative dengan pemerintahan di Kecamatan maupun Kabupaten sehingga semua kebijakan public yang bertujuan untuk Meningkatkan kesejahteraan warga desa dapat diketahui, dimengert dan diraskan manfaatnya oleh masyarakat Desa PH. Di pihak lain selayaknya aparatur pemerintahan di Kecamatan BBL dan Kabupatyen Bekasi juga secara aktif untuk memperhatikan desa yang relative jauh dari pusat pemerintahan kabupaten.

Upaya melakukan sosialisasi terhadap kebijakan public yang bertujuan meningkatkan kesejahteraan masyarakat harus terus menerus dilakukan. Dengan sosialisasi yang berkelanjutan dan terjadwal, hambatan tentang keterlambatan informasi bisa diatasi. Penyederhaan perijinan 
yang menyangkut koordinasi antar unit di pemerintahan dapat disederhanakan. Jika ini dilakukan dengan baik, maka masyarakat juga akan lebih responsive terhadap program pemerintah, dan pihak - pihak yang mencari keuntunganpun akan menghilangkan karena semua kegiatan dilakukan dengan cepat dan terkoordinasi dengan baik.

\section{Ucapan Terima Kasih (Acknowledgement)}

Terimakasih kepada para informan dan tokoh masyarakat yang mendukung dalam penelitian di Desa PH Kecamatan BBL Terima kasih juga kepada pihak-pihak (teman-teman) yang tidak dapat disebutkan atas bantuan dalam melakukan kategorisasi dan pengelompokan data dan informasi.

\section{REFERENSI}

Agustino, L. (2016). Dasar-dasar kebijakan publik. Bandung: Alfabeta.

Akib, H. (2010). Implementasi kebijakan: Apa, mengapa, dan bagaimana. Jurnal Administrasi Publik, 1(1). 1-1. Diakses dari https://doi.org/10.26858/jiap.v1i1.289

Anderson, J. E. (2003). Public policymaking: An introduction. Boston: Houghton Mifflin Company.

Badri, M. (2017). Sistem komunikasi pembangunan pedesaan berbasis teknologi informasi dan komunikasi. Prosiding: Akselerasi Pembangunan Masyarakat Lokal Melalui Komunikasi dan Teknologi Informasi. Universitas Lampung, 1(1), 41-53.

Bungin, B. (2016). Metode penelitian kualitatif. Jakarta: PT. Raja Grafindo Persada

Elvina \& Musdhalifah. (2019). Peningkatan kesejahteraan masyarakat melalui partisipasi dan implementasi kebijakan dengan efektivitas pembangunan program dana desa sebagai variabel intervening. Jurnal Sosial Humaniora dan Pendidikan. Politeknik Negeri Balikpapan, 3(1) 1-9. Diakses dari https://doi.org/10.32487/jshp.v3i1.509

Evans, S. J. (2008). Public policy issues research trends. New York: Nova Science Publisher Inc Fahturrahman, M. (2016). Faktor birokrasi dalam keberhasilan implementasi kebijakan publik. Jurnal TARBAWI, 2(2), 14-27. Diakses dari https://media.neliti.com/media/publications/256485-faktor-birokrasi-dalam-keberhasilanimpl-6defc895.pdf

Faisal, S. (2015). Format - format penelitian sosial. Jakarta: Raja Grafindo Persada.

Kencana, S. I. (2016). Ilmu administrasi publik. Jakarta: Rineka Cipta.

Koentjaraningrat. (2012). Kebudayaan, mentalitas dan pembangunan. Jakarta: Gramedia.

Koeswara, H. (2019). Dana Desa: Apakah Solusi Mengatasi Persoalan Keuangan Desa?. Jurnal Administrasi dan Kebijakan Publik, Universitas Andalas, 4(1), 12-21. Diakses dari https://doi.org/10.25077/jakp.4.1.12-21.2019

Lesmana, H. (2017). Peningkatan Kapasitas Kepala Desa Dan Aparatur Desa (Studi Terhadap Penyusunan Perencanaan Pembangunan Desa Dalam Pengelolaan Dana Desa Panggak Laut Kecamatan Lingga Kabupaten Lingga). Jurnal Ilmu Administrasi Negara Raja Ali Haji, 5(2), 9-18.

Moleong, J. L. (2018). Metoda penelitian kualitatif. Bandung: PT. Remaja Rosdakarya.

Monografi Desa. (2017). Desa PH Kecamatan BBL, Kabupaten Bekasi Provinsi Jawa Barat.

Muliawaty, L. \& Hendryawan, S. (2020). Peranan e-government dalam pelayanan publik (studi kasus: Mal pelayanan publik Kabupaten Sumedang). Kebijakan: Jurnal Ilmu Administrasi, $11(2), \quad$ 45-57. Diakses dari http://dx.doi.org/10.23969/kebijakan.v11i2.2898

Mulyadi, D. (2019) Implementasi kebijakan pemberian bantuan keuangan kepada pemerintah desa di Kabupaten Bandung. Jurnal Ilmu Administrasi, 16(1), 66-80. Diakses dari http://180.250.247.102/index.php/jia/article/view/208/pdf 
Noviyanti, L \& Soleh, A. Z. (2017). Peningkatan keterampilan perangkat desa melalui statistika di desa sayang kecamatan jatinangor Kabupaten Sumedang. Jurnal Pengabdian Kepada Masyarakat, $\quad$ l(2), 129-133. Diakses dari http://journal.unpad.ac.id/pkm/article/viewFile/16304/7960

Patarai, M. I. (2020). Kebijakan publik daerah: Posisi dan dimensinya dalam perspektif desentralisasi kebijakan. Makassar: De La Macca.

Roso, S. D. (2019). Studi tentang indikator stratifikasi sosial masyarakat tani di Kecamatan Sungai Lilin Kabupaten Musi Banyuasin (Skrispi). Universitas Muhammadiyah Palembang, Palembang. Diakses dari http://repository.um-palembang.ac.id/id/eprint/3949

Soekanto, S. (2017) Sosiologi suatu pengantar. Jakarta: Rajawali Pers.

Sugiyono. (2016). Metode penelitian pendidikan: Pendekatan kuantitatif, kualitatif, dan $r \& d$. Bandung: Alfabeta.

Sunarno, S. (2012). Hukum pemerintahan daerah di Indonesia. Jakarta: Sinar Grafika Offset.

Susanto, E. H. (2009). Komunikasi politik dan otonomi daerah: tinjauan terhadap dinamika sosial, ekonomi, politik dan pembangunan. Jakarta: Mitra Wacana Media.

Syarif, A., \& Zainuddin, M. (2017) Inti sari sosiologi pertanian. Makassar: Inti Mediatama.

Thoha, M. (2017). Dinamika ilmu administrasi publik. Jakarta: Kencana.

Undang-Undang Republik Indonesia Nomor 6 Tahun 2014 tentang Desa. Jakarta: Kementerian Dalam Negeri

Wijayanti, P. W. \& Pratomo, R. A. (2019). Keberlanjutan wilayah: keterkaitan desa-kota dalam aktivitas minapolitan di Kabupaten Malang. Jurnal Perencanaan Pembangunan Wilayah dan Perdesaan, 3(3), 180-188. Diakses dari https://doi.org/10.29244/jp2wd.2019.3.3.180-188

Winarno, B. (2012). Kebijakan publik: Teori, proses dan studi kasus. Yogyakarta: Media Presindo.

Wiranata, I. G. A. B. (2011). Antropologi budaya. Bandung: Citra Adytia Bakti. 